\title{
Isolation and Characterization of Novel Microsatellite Markers in Chayote [Sechium edule (Jacq.) Sw.]
}

\author{
Ryoko Machida-Hirano', Moisés Cortés-Cruz², Blanca Amalia Amaro González², \\ Jorge Cadena Íñiguez ${ }^{3}$, Kazuto Shirata ${ }^{1,4}$, Kazuo N. Watanabe ${ }^{{ }^{*}}$ \\ ${ }^{1}$ Gene Research Center, University of Tsukuba, Tsukuba, Japan \\ ${ }^{2}$ Centro Nacional de Recursos Genéticos, Instituto Nacional de Investigaciones Forestales, \\ Agrícolas y Pecuarias, Tepatitlán de Morelos, México \\ ${ }^{3}$ Colegio de Postgraduados, Campus San Luis Potosí, Salinas de Hidalgo, Mexico \\ ${ }^{4}$ National Institute of Agrobiological Sciences, Tsukuba, Japan \\ Email: ${ }^{*}$ nabechan@gene.tsukuba.ac.jp
}

Received 30 June 2015; accepted 20 August 2015; published 26 August 2015

Copyright (C) 2015 by authors and Scientific Research Publishing Inc.

This work is licensed under the Creative Commons Attribution International License (CC BY).

http://creativecommons.org/licenses/by/4.0/

(c) (i) Open Access

\begin{abstract}
Chayote [Sechium edule (Jacq.) Sw.] is an economically important species in Latin America; however, there are very few reports available regarding its genetic diversity. Out of 11 microsatellite markers isolated, 10 loci provided 1 to 7 alleles per locus in a set of Mexican chayote accessions. Observed and expected heterozygosities for each locus ranged from 0.00 to 0.85 and 0.00 to 0.73 , respectively. The overall genetic diversity detected by microsatellites was compared with that detected by $\mathbf{P 4 5 0}$-based analogue markers, a genome-wide dominant marker. Genetic diversity values obtained by the newly designed microsatellite markers were almost equal to the value estimated by PBA markers, but genetic distances calculated by both marker systems were not significantly correlated. Additional microsatellite markers, which could detect more polymorphisms, may be necessary to analyze the genetic diversity and structure of Mexican chayote collections.
\end{abstract}

\section{Keywords}

Chayote, SSR Markers, PBA Markers, Dual-Suppression-PCR Technique, Genetic Diversity

\section{Introduction}

Chayote [Sechium edule (Jacq.) Sw.] is an economically important species of Cucurbitaceae in Latin America;

"Corresponding author.

How to cite this paper: Machida-Hirano, R., Cortés-Cruz, M., González, B.A.A., Íñiguez, J.G., Shirata, K. and Watanabe, K.N. (2015) Isolation and Characterization of Novel Microsatellite Markers in Chayote [Sechium edule (Jacq.) Sw.]. American Journal of Plant Sciences, 6, 2033-2041. http://dx.doi.org/10.4236/ajps.2015.613203 
however, very few reports are available regarding its genetic diversity. Commercial production for local consumption and export of the fresh fruit is a significant source of revenue and local employment in Mexico [1]-[4] The most popular variety, "Verde Liso" (Smooth Green), has exported to international market and created local employments [1] [5]. In addition, it is also an important staple food for low-income groups in Latin America and is commonly grown in home gardens for family consumption [6]. In addition to consuming the fruits as vegetable, the tuberous roots are rich sources of starch and the shoots and young leaves are cooked as pot-herb [7].

Historical records and linguistics, occurrence of wild forms, and the distribution of related wild species indicate that the geographical origin is in tropical America, especially in Mexico and Central America [7]-[9]. In Mexico, the highest levels of chayote diversity exist in the states of Veracruz, Chiapas, and Oaxaca, especially in the central region of Veracruz where significant variation in fruit size, form and color, flavor, and skin texture (smooth or with spines) has been reported [10].

Although morphological variation has been reported [9] [10], studies on genetic diversity of chayote have been limited to the use of isozymes [11] [12] and AFLP [13]. Hyper variable molecular markers, such as microsatellites, offer higher resolving power for population genetics and are widely used to study genetic diversity, population structure, and genetic relatedness [14]. However, such tools are not available for chayote despite its economic importance. Therefore, development of species-specific molecular markers is needed to elucidate the genetic structure of the species.

In this paper, first we report the design of 11 species-specific microsatellite markers using Japanese chayote varieties. Second, the designed markers were evaluated by using 20 Mexican chayote accessions. Finally, results of genetic diversity analysis with the newly designed microsatellite markers were compared with those detected by P450-based analogues (PBAs) markers [15], which had been used to assess genome-wide diversity of P450related functional genes on different plant species [16]-[19].

\section{Materials and Methods}

\subsection{Microsatellite Marker Design and Evaluation}

Total genomic DNA was extracted from dried leaves of the Japanese local variety of chayote, "Zairai Wase", by CTAB method [20]. Microsatellites were developed according to a previously described dual-suppression-PCR technique [21]. First, DNA was digested with Alu I, Eco RV, Hae III, and Ssp I restriction enzymes to construct four DNA libraries. The restricted fragments were then ligated by using a DNA Ligation Kit Ver.2.1 (Takara Bio, Japan) with specific blunt adaptors (the first consisted of a 48-mer:

5'-GTAATACGACTCACTATAGGGCACGCGTGGTCGACGGCCCGGGCTGGT-3' and the second consisted of an 8-mer, with the 3'-end capped by an amino residue: 5'-ACCAGCCC- $\mathrm{NH}_{2}-3$ ').

Flanked regions of the microsatellite were isolated from these four DNA libraries by amplification using compound microsatellite primers (AC) 10 or (GA) ${ }_{10}$ and the adaptor primer AP2 (5'-CTATAGGGCACGCGTGGT-3') designed from the 48-mer adapter. The amplified fragments were then integrated into a plasmid pGEM-T vector using pGEM-T Easy Kit (Promega); the plasmids were then transferred into Escherichia coli DH5 $\alpha$, according to the manufacturer's instructions. The cloned fragments were amplified from the extracted plasmid DNA of positive clones using M13 forward and M13 reverse primers. The size of inserted fragments were checked by $1 \%$ agarose gel electrophoresis and the PCR products were directly sequenced with the M13(-21) primer using BigDye Terminator v3.1 Cycle Sequencing Kit (Life Technology) in the ABI 3130 Genetic Analyzer (Life Technology). Each fragment containing $(\mathrm{AC})_{\mathrm{n}}$ or $(\mathrm{GA})_{\mathrm{n}}$ sequence at one end was chosen for the next step.

The next step consisted of determining the sequence of the other flanking regions for each microsatellite. A pair of primers, IP1 and IP2, was designed from each sequence. IP1 was a nested specific primer, designed from the flanking region of the microsatellites, whereas IP2 was designed based on the sequence between IP1 and the microsatellite. All these primers were designed using Primer3Plus [22]. An adapter-primer for nested PCR (AP1: 5'-CCATCGTAATACGACTCACTATAGGGC-3', designed from the 48-mer adaptor sequence) was also prepared. Primary PCR reactions were conducted on each constructed DNA library using the combination of IP1 and AP1 primers. Secondary PCR was conducted with a 100-fold dilution of the primary PCR products with IP2 and AP2. Single-banded fragments were then sub-cloned and sequenced. Finally, the primers IP3-forward and IP3-reverse were designed for each locus from the newly identified sequence between the AP2 and microsatellite sequences. The primer pairs IP3-forward/IP3-reverse were defined as the newly designed microsatellite markers. 
Amplification of the newly designed markers was tested on 20 Mexican chayote accessions comprising 10 varietal groups with different fruit morphological characteristics (Supplementary Table 1). To obtain fluorescent-labeled products, amplification reactions were carried out using a $10 \mu \mathrm{l}$ three-primer combination [23] as follows: 10 ng of genomic DNA; $5 \mu$ of RedTaq ${ }^{\circledR}$ ReadyMix $^{\mathrm{TM}}$ PCR Reaction Mix (Sigma-Aldrich); and 0.2 $\mu \mathrm{M}$ of fluorescent-labeled universal primer, $1.5 \mu \mathrm{M}$ of locus-specific forward primer with 5' universal tails sequence, and $0.5 \mu \mathrm{M}$ of locus specific reverse primer. PCR products were amplified using the following parameters: initial denaturation at $95^{\circ} \mathrm{C}$ for $3 \mathrm{~min}$; followed by 30 cycles of $95^{\circ} \mathrm{C}$ for $30 \mathrm{~s}, 60^{\circ} \mathrm{C}$ for $30 \mathrm{~s}$, and $72^{\circ} \mathrm{C}$ for 1 min; and a final elongation step at $72^{\circ} \mathrm{C}$ for $1 \mathrm{~h}$. The size of the PCR products was determined by capillary sequencer (3500 ×l Genetic Analyzer, Life Technologies).

General genetic diversity values were calculated at each locus. Pair-wise genetic distances among 20 individuals were calculated using "Codom-Genotypic" option to enable comparisons between codominant (microsatellites) and dominant (PBA) data output. Principal coordinate analysis (PCoA) was also carried out. All these analyses were carried out using GenAlEx 6.5 [24]. Polymorphism information content (PIC) of each marker was calculated using a PIC calculator [25]. The characteristics of the microsatellite markers for Mexican chayote are shown in Table 1.

Table 1. Characteristics of 11 microsatellite loci in Sechium edule. The observed and expected heterozygosity were calculated for the 20 individuals of Mexican chayote.

\begin{tabular}{|c|c|c|c|c|c|c|c|c|c|c|}
\hline Locus & & Primer sequence 5' > 3' & Repeat motif & Genbank no. & Size $^{\mathrm{a}}(\mathrm{bp})$ & $\mathrm{N}$ & $\mathrm{Na}$ & Ho & He & PIC \\
\hline \multirow[t]{2}{*}{ Sed 01} & $\mathrm{~F}:$ & CCCCGTTACCCTGACTCTCGAT & $(\mathrm{CA})_{8}$ & AB871395 & 196 & 20 & 2 & 0.85 & 0.50 & 0.37 \\
\hline & $\mathrm{R}:$ & GGCTTGTTCAAGACTTCGCAGC & & & & & & & & \\
\hline \multirow[t]{2}{*}{ Sed 02} & $\mathrm{~F}:$ & AGAAGACGACACACTTTTGAGCA & $(\mathrm{CA})_{2} \mathrm{C}(\mathrm{CA})_{5}$ & AB871396 & 316 & 20 & 1 & 0.00 & 0.00 & 0.00 \\
\hline & $\mathrm{R}:$ & ATCTACCCGTGACTGCCCAGAT & & & & & & & & \\
\hline \multirow[t]{2}{*}{ Sed 03} & $\mathrm{~F}:$ & CGTATGGTCGAGGTGCGCATAA & $(\mathrm{CA})_{9}$ & AB871397 & 144 & 20 & 5 & 0.15 & 0.51 & 0.48 \\
\hline & $\mathrm{R}:$ & AAGTCCAGAAATGTACACTGCCACT & & & & & & & & \\
\hline \multirow[t]{2}{*}{ Sed 04} & $\mathrm{~F}:$ & GGCCCTTAGTTTGCTGATGGGT & $(\mathrm{CA})_{2} \mathrm{CT}(\mathrm{CA})_{2} \mathrm{CC}(\mathrm{CA})_{3}$ & AB871398 & 378 & 20 & 1 & 0.00 & 0.00 & 0.00 \\
\hline & $\mathrm{R}:$ & TGGGACCCACGTGCTAAAAGTG & & & & & & & & \\
\hline \multirow[t]{2}{*}{ Sed 05} & $\mathrm{~F}:$ & ACACACCTTAGAAAGAGCAACCCC & $(\mathrm{CA})_{2} \mathrm{CGA}(\mathrm{CA})_{5}$ & AB871399 & 274 & 20 & 1 & 0.00 & 0.00 & 0.00 \\
\hline & $\mathrm{R}:$ & GCTATGGCGCAAGTTGCTGATG & & & & & & & & \\
\hline \multirow[t]{2}{*}{ Sed 06} & $\mathrm{~F}:$ & AACCGCTGTTCTCTGCTCATCC & $(\mathrm{CA})_{4} \mathrm{TA}(\mathrm{CA}){ }_{16}$ & AB871400 & 229 & 20 & 3 & 0.15 & 0.14 & 0.14 \\
\hline & $\mathrm{R}:$ & GGCTCAAGGTTGTTGTTGGTGC & & & & & & & & \\
\hline \multirow[t]{2}{*}{ Sed 07} & $\mathrm{~F}:$ & AACCTGGGTCGTTACATGGTGC & $(\mathrm{GA})_{34}$ & AB871401 & 359 & 20 & 3 & 0.15 & 0.22 & 0.21 \\
\hline & $\mathrm{R}:$ & ACССTTGCCCTAGATGGTGGAA & & & & & & & & \\
\hline \multirow[t]{2}{*}{ Sed 08} & $\mathrm{~F}:$ & AGCTССТССАССТСТАССТTTTGC & $(\mathrm{GA})_{3} \mathrm{GC}(\mathrm{GA})_{5}$ & AB871402 & 382 & 20 & 3 & 0.15 & 0.14 & 0.14 \\
\hline & $\mathrm{R}:$ & ACTCTGGCGTATGGAATGACGC & & & & & & & & \\
\hline \multirow[t]{2}{*}{ Sed 09} & $\mathrm{~F}:$ & ACAGGCCACAGGGGAACAAAAT & $(\mathrm{GA})_{11}$ & AB871403 & 204 & 20 & 5 & 0.20 & 0.57 & 0.51 \\
\hline & $\mathrm{R}:$ & CACGCCATCTCCGTCCATCTTT & & & & & & & & \\
\hline \multirow[t]{2}{*}{ Sed 11} & $\mathrm{~F}:$ & TGGTCTGTTTGGCTCATCTCCA & $(\mathrm{GA})_{14}$ & AB871405 & 299 & 20 & 7 & 0.11 & 0.73 & 0.68 \\
\hline & $\mathrm{R}:$ & TCGACСССТAACCCTTGAAGCT & & & & & & & & \\
\hline Mean & & & & & & 20 & 3.1 & 0.21 & 0.28 & 0.25 \\
\hline
\end{tabular}

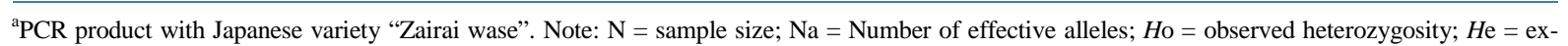
pected heterozygosity; PIC = polymorphism information content. 


\subsection{Genetic Diversity Analysis of PBA Marker}

Genetic diversity values from the same set of Mexican chayote samples were evaluated using PBA markers [11] [15]. The PBA primer sets comprised of three forward primers (CYP1A1F, CYP2B6F, and CYP2C19F) and three reverse primers (CYP1A1R, CYP2B6R, and CYP2C19R). Nine combinations of these primer pairs were tested and eight of them produced scorable bands (Table 2). PCR amplifications were performed using $10 \mathrm{ng}$ of template DNA in a total reaction mixture of $10 \mu$ containing $5 \mu$ of RedTaq ${ }^{\circledR}$ ReadyMix ${ }^{\mathrm{TM}}$ (Sigma-Aldrich) and $0.18 \mu \mathrm{M}$ each of forward and reverse primers. This PCR was run at $94^{\circ} \mathrm{C}$ for $5 \mathrm{~min}$, followed by 30 cycles of $94^{\circ} \mathrm{C}$ for $1 \mathrm{~min}$, annealing temperature for $2 \mathrm{~min}$, and $72^{\circ} \mathrm{C}$ for $3 \mathrm{~min}$, with a final extension of $72^{\circ} \mathrm{C}$ for $10 \mathrm{~min}$. Annealing temperature varied for each primer set, as shown in Table 2. PCR products were electrophoresed using $6 \%$ of acrylamide gels at $150 \mathrm{~V}$ for $3 \mathrm{~h}$, followed by silver staining.

For statistical analysis, amplified DNA fragments were scored in a binary data matrix, where the presence of band was denoted as 1 and its absence as 0 . A single data matrix was prepared by combining genotyping results of 8 primer combinations and general genetic diversity values were calculated. Genetic distances among individuals were calculated and PCoA was also carried out. The correlation between estimates of genetic distances based on PBA and microsatellite data was determined by Mantel test [26]. All data analyses were carried out using GenAlEx 6.5 [24].

\section{Results and Discussions}

\subsection{Design of Microsatellite Markers for Chayote and Genetic Diversity Values of Mexican Chayote}

A total of 40 clones from the (AC) $)_{10}$ and 24 clones from the (GA) $)_{10}$ libraries were randomly chosen based on amplification size ( $\geq 500 \mathrm{bp}$ ) and were sequenced. Eighteen (45\%) and 9 (37.5\%) clones, respectively, from each library, had enough sequence length to design two primers between repeat motif and adapter sequences, and they were used to design IP1 and IP2 primers. In total, 15 primer pairs were designed, 7 from the (AC) $)_{10}$ library and 8 from the $(\mathrm{GA})_{10}$ library. These primers were initially tested on a subset of $S$. edule individuals from the Japanese varieties to confirm reliable amplification. Of these, 4 amplified multiple loci while 11 were polymorphic and produced a single band (GenBank accession no.: AB871395 to AB871405).

Specie-specificity of the newly designed markers was confirmed by cross amplification with arbitrary selected other plant species. Four genotypes of heliconias (Heliconia bourgaeana, H. bihai, H. collinsiana and H. uxpanapensis) and four chayote genotypes were tested with primers designed in this study. Amplifications were observed only from chayote DNA samples, and not from heliconias. Equally, cross-amplification of microsatellite markers designed for heliconias (Hac-A116 and Hac-D1) [27] were tested with chayote samples. PCR products were observed only in the four Heliconia spp. DNA samples (Supplemental Figure 1). DNA sequences from the selected libraries were used to do a homology search against NCBI Nucleotide collection database (http://www.ncbi.nlm.nih.gov/), using blastn and no significantly high homology sequences were found (data not shown), confirming that DNA from chayote was used during the primers design and that DNA cross contamination with other species was avoided.

Table 2. Combinations of PBA markers used in this study.

\begin{tabular}{ccc}
\hline Primer pairs/combinations & Annealing temp. $\left({ }^{\circ} \mathrm{C}\right)$ & Number of polymorphic bands \\
\hline CYP1A1F/CYP1A1R & 56 & 15 \\
CYP1A1F/CYP2B6R & 52 & 47 \\
CYP1A1F/CYP2C19R & 52 & 5 \\
CYP2B6F/CYP1A1R & 47 & 5 \\
CYP2B6F/CYP2C19R & 52 & 14 \\
CYP2B6F/CYP2B6R & 56 & 17 \\
CYP2C19F/CYP1A1R & 47 & 2 \\
CYP2C19F/CYP2C19R & - & 11 \\
Average & & 4 \\
\hline
\end{tabular}


The 11 polymorphic primer pairs were further tested on 20 individuals from a Mexican collection (BANGESe, National Sechium edule Germplasm Bank, Huatusco, Veracruz, Mexico). One primer combination (Sed10) was discarded from further analysis because it produced too much stutter bands and size determination was not possible. Out of 10 loci tested, 7 microsatellites showed polymorphism, ranging from 1 to 7 alleles per locus (Table 1). The mean values for effective allele number, observed heterozygosity (Ho), and expected heterozygosity $(\mathrm{He})$ were $3.1,0.21$, and 0.28 , respectively. Polymorphism information values ranged from 0.00 to 0.68 . The proportion of polymorphic loci was 70\%, whereas isozyme studies reported 59.8\% [5] and 57.14\% [11], suggesting that microsatellite markers had higher resolution in detecting polymorphisms within chayote varieties.

Among 20 Mexican chayote individuals tested, only one pair (SE-369 and SE-288) demonstrated identical patterns of allelic combinations, both of them belonged to the same varietal group, albus levis, and share identical fruit characteristics. However, individuals that belonged to other varietal groups (e.g., albus minor, SE-261 and SE-330) exhibited different genotyping patterns. There is still a need for development of additional markers to increase resolution so that microsatellite markers can be used for genotype identification and, in some cases, for marker-assisted selection. However, these results suggest that the DNA profiles based on the application of newly designed microsatellite markers could be used to differentiate chayote individuals and accessions.

\subsection{Low Heterozygosity Detected in Chayote Collection}

Chayote is known as a predominantly cross-pollinated species but its low heterozygosity is reported by isozyme studies [1] [11]. In the present study, 9 out of 10 newly designed microsatellite markers also detected low level of heterozygosity $(\mathrm{Ho}=0.00$ to 0.20$)$, except for Sed $01(\mathrm{Ho}=0.85)$. Other genetic diversity studies on Cucurbitaceae using microsatellite markers demonstrated moderate to high heterozygosity $(0.49-0.75$ [28], 0.26 0.79 [29], $0.00-1.00$ [30], and 0.325 - 0.867 [31]). Although individual species in the Cucurbitaceae family are generally cross-pollinated, chayote is known to be self-compatible [32] and a single plant of chayote shows a good fruit set and does not demonstrate clear inbreeding symptoms [33]. Therefore, cross-pollination rate in cultivated chayote may not be as high as assumed, since chayote is typically cultivated in home gardens and a small number of plants are used for seed source [11]. Reference [34] also reported low heterozygosity values (range $0.00-0.50$ ) in melon samples evaluated with a set of 25 microsatellites and mentioned possible favoring endogamy in cultivated populations. Pollination with self and/or among close relatives during domestication and cultivation of the species may have contributed to the observed low heterozygosity values.

\subsection{Relationship between Morphological Characters and Genetic Marker Grouping Patterns}

Although the set of Mexican chayote collection consisted of a broad range of varietal group with high diversity in fruit morphology (Supplementary Table 1), the scatter diagram of the PCoA derived by both microsatellite and PBA markers did not show a clear distribution pattern associated with a varietal group or fruit morphological characteristics (data not shown). Fruit morphological characteristics, such as color, shape, size, taste, and presence/absence of spines, are not environmental adaptation-related traits, unless directional selections by humans have strongly influenced chayote domestication. In addition, [35] reported that spines on fruits can be controlled by gibberellic acid application during development. Therefore, a clear relationship between genetic and morphological groupings may not have been observed.

\subsection{Comparison of Microsatellites and PBA Marker Systems in Detecting Genetic Diversity}

From the 9 primer combinations evaluated for the PBA markers, 8 showed polymorphisms on the same set of Mexican chayote samples. The total number of polymorphic bands was 88, ranging from 2

(CYP2C19F/CYP2C19R) to 17 (CYP2C19F/CYP1A1R) (Table 2). The mean He value calculated with the PBA marker system was almost the same as that obtained by the microsatellite marker system $(0.29$ vs. 0.28 , respectively), indicating that the 10 newly designed microsatellite markers in this study were useful in detecting genetic diversity levels of a Mexican chayote collection set. Mantel test showed that there was no significant correlation between the respective genetic distances estimated by the microsatellite and PBA data $(r=-0.051 ; p$ $=0.40$ ). This may be due to the existence of a genome-wide distribution of P450-related functional genes, which 
are detected by PBA markers, whereas microsatellites are detected polymorphisms at a single locus. These results highlight the different properties of each marker system. In a multivariate analysis by using microsatellite and PBA markers in rice, it also revealed different distribution patterns, and mentioned that the different types of molecular markers might contribute in the different aspects of the genetic structure [19]. Therefore, evaluation of genetic diversity combining different assessment methods would be helpful, especially for the species lack number of species specific markers available.

\section{Conclusion}

Microsatellite markers are widely used for fingerprinting and diversity studies of different species. In this study, we reported the design of 11 microsatellite markers for chayote. Ten of them were easily genotyped and 7 of them detected polymorphisms in a set of Mexican chayote accessions. When compared with the results obtained by 8 combinations of PBA markers, the genetic diversity indicators calculated by these microsatellites were almost equivalent but demonstrated different grouping patterns. However, the designed markers sets were not efficient enough to discriminate clearly different genotypes. It may be necessary to develop more microsatellite markers in order to detect more polymorphisms, more precise genotyping, and larger scale genetic diversity germplasm collections. Currently, development of additional microsatellite markers is under process and these markers will be useful to characterize population genetic structures of chayote varieties of Mexico and Latin America and to decipher the dynamics of its genetic diversity.

\section{Acknowledgements}

This research was supported by JST/JICA, SATREPS (Science and Technology Research Partnership for Sustainable Development) "Diversity Assessment and Development of Sustainable Use of Mexican Genetic Resources: a SATREPS Project”, Japan, INIFAP and Interdisciplinary Research Group Sechium edule in Mexico (GiSeM).

\section{References}

[1] Avendaño-Arrazate, C.H., Cadena-Íñiguez, J., Arévalo-Galarza, M.L., Campos-Rojas, E., Cisneros-Solano, V.M. and Aguirre-Medina, J.F. (2010) Las variedades del chayote Mexicano, recurso ancestral con potencial de comercialización. Grupo Interdisciplinario de Investigación en Sechium edule en México A.C. (GISeM), Mexico (in Spanish).

[2] Cadena-Iñiguez, J., Arévalo-Galarza, L., Avendaño-Arrazate, C., SotoHernández, M., Ruiz-Posadas, L., SantiagoOsorio, E., Acosta-Ramos, M., Cisneros-Solano, V., Aguirre-Medina, J. and Ochoa-Martínez, D. (2007) Production, Genetics, Postharvest Management and Pharmacological Characteristics of Sechium edule (Jacq.) Sw. In: Teixeira da Silva, J., Ed., Fresh Produce,Vol. 1, Global Science Books, Middlesex, 41-53.

[3] Flores, M.E. (1989) El Chayote, Sechium edule Swartz (Cucurbitaceae). Revista de Biología Tropical, 37, 1-54 (in Spanish).

[4] Cadena-Iñiguez, J., Ruiz-Posadas, L.M., Trejo-López, C., Sánchez-García, P. and Aguirre-Medina, J.F. (2001) Intercambio de gases y relaciones hídricas del chayote (Sechium edule (Jacq.) Sw). Revista Chapingo, 7, 21-35 (in Spanish).

[5] Cadena-Iñiguez, J. and Arévalo-Galarza, M.L.C. (2011) Las variedades del chayote (Sechium edule (Jacq) Sw.) y su comercio mundial. Primera edición Mundi Prensa México (in Spanish).

[6] Lira, R. (1995) Estudios taxonómicos y ecogeográficos de las Cucurbitáceas latinoamericanas de importancia económica. Systematic and ecogeographic studies on crop genepools. 9. International Plant Genetic Resources Institute, Rome (in Spanish).

[7] Newstrom, L.E. (1990) Origin and Evolution of Chayote. In: Bates, D.M., Robinson, R.W. and Jeffrey, C., Eds., Biology and Utilization of the Cucurbitaceae, Cornell University Press, Ithaca, New York, 141-149.

[8] Bates, M.D., Merrick, L.C. and Robinson, R.W. (1995) 24 Minor Cucurbits. In: Smartt, J. and Simmonds, N.W., Eds., Evolution of Crop Plants, 2nd Edition, Wiley-Blackwell, New York, 105-111.

[9] Lira, S.R. (1996) Chayote. Sechium edule (Jacq.) Sw. Promoting the Conservation and Use of Underutilized and Neglected Crops. 8. Institute of Plant Genetics and Crop Plant Research, Gatersleben/International Plant Genetic Resources Institute, Rome.

[10] Cadena-Íñiguez, J., Avendaño-Arrazate, C.H., Soto-Hernández, M., Ruiz-Posadas, L.M., Aguirre-Medina, J.F. and Arévalo-Galarza, L. (2008) Infraspecific Variation of Sechium edule (Jacq.) Sw. in the State of Veracruz, Mexico. Genetic Resources and Crop Evolution, 55, 835-847. http://dx.doi.org/10.1007/s10722-007-9288-4 
[11] Abdelnour, A. and Rocha, O.J. (2008) Genetic Characterization of a Collection of Chayote, Sechium edule (Jacq.) Swartz, in Costa Rica by Using Isozyme Markers. Genetic Resources and Crop Evolution, 55, 163-170. http://dx.doi.org/10.1007/s10722-007-9225-6

[12] Avendaño-Arrazate, C.H., Cadena-Íñiguez, J., Arévalo-Galarza, M.L., Cisneros-Solano, V.M., Aguirre-Medina, J.F., Moreno-Pérez, E.D.C., Cortés-Cruz, M., Castillo-Martínez, C.R. and Ramírez Vallejo, P. (2012) Variación genética en el complejo infraespecífico de chayote evaluada mediante sistemas isoenzimáticos. Pesquisa Agropecuária Brasileira, 47, 244-252 (in Spanish).

[13] Cross, H., Lira Saade, R. and Motley, T.J. (2006) Origin and Diversification of Chayote. In: Motley, T.J., Zerega, N. and Cross, N., Eds., Darwin's Harvest, Columbia University Press, New York, 171-194.

[14] Nybom, H., Weising, K. and Rotter, B. (2014) DNA Fingerprinting in Botany: Past, Present and Future. Investigative Genetics, 5, 1. http://dx.doi.org/10.1186/2041-2223-5-1

[15] Yamanaka, S., Suzuki, E., Tanaka, M., Takeda, Y., Watanabe, J.A. and Watanabe, K.N. (2003) Assessment of Cytochrome P450 Sequences Offers a Useful Tool for Determining Genetic Diversity in Higher Plant Species. Theoretical and Applied Genetics, 108, 1-9. http://dx.doi.org/10.1007/s00122-003-1403-0

[16] Gilani, S.A., Kikuchi, A. and Watanabe, K.N. (2009) Genetic Variation within and among Fragmented Populations of Endangered Medicinal Plant, Withania coagulans (Solanaceae) from Pakistan and Its Implications for Conservation. African Journal of Biotechnology, 8, 2948-2958.

[17] Jatoi, S.A., Kikuchi, A., Ahmad, D. and Watanabe, K.N. (2010) Characterization of the Genetic Structure of Mango Ginger (Curcuma amada Roxb.) from Myanmar in Farm and Genebank Collection by the Neutral and Functional Genomic Markers. Electronic Journal of Biotechnology, 13, 1-11.

[18] Yamanaka, S., Ikeda, S., Imai, A., Luan, Y., Watanabe, J.A. and Watanabe, K.N. (2005) Construction of Integrated Genetic Map between Various Existing DNA Markers and Newly Developed P450-Related PBA Markers in Diploid Potato (Solanum tuberosum). Breeding Science, 55, 223-230. http://dx.doi.org/10.1270/jsbbs.55.223

[19] Yamanaka, S., Jatoi, S.A., San-Yi, S., Kothari, S.L. and Htut, T. and Watanabe, K.N. (2011) Genetic Diversity of Myanmar Rice and Their Implementation on Management Methods. African Journal of Biotechnology, 10, 1290-1298.

[20] Doyle, J.J. and Doyle, J.L. (1987) A Rapid DNA Isolation Procedure for Small Quantities of Fresh Leaf Tissue. Phytochemical Bulletin, 19, 11-15.

[21] Lian, C. and Hogetsu, T. (2002) Development of Microsatellite Markers in Black Locust (Robinia pseudoacacia) Using a Dual-Suppression-PCR Technique. Molecular Ecology Notes, 2, 211-213.

[22] Untergasser, A., Nijveen, H., Rao, X., Bisseling, T., Geurts, R. and Leunissen, J.A.M. (2007) Primer3Plus, an Enhanced Web Interface to Primer3. Nucleic Acids Research, 35, W71-W74. http://dx.doi.org/10.1093/nar/gkm306

[23] Blacket, M.J., Robin, C., Good, R.T., Lee, S.F. and Miller, A.D. (2012) Universal Primers for Fluorescent Labelling of PCR Fragments-An Efficient and Cost-Effective Approach to Genotyping by Fluorescence. Molecular Ecology Resources, 12, 456-463. http://dx.doi.org/10.1111/j.1755-0998.2011.03104.x

[24] Peakall, R. and Smouse, P.E. (2012) GenAlEx 6.5: Genetic Analysis in Excel. Population Genetic Software for Teaching and Research—An Update. Bioinformatics, 28, 2537-2539. http://dx.doi.org/10.1093/bioinformatics/bts460

[25] Kemp, S. (2002) PIC Calculator Extra. http://www.liv.ac.uk/ kempsj/pic.html.

[26] Mantel, N. (1967) The Detection of Disease Clustering and a Generalized Regression Approach. Cancer Research, 27, 209-220.

[27] Côrtes, M., Gowda, V., Kress, W., Bruna, E.M. and Uriarte, M. (2009) Characterization of 10 Microsatellite Markers for the Understorey Amazonian Herb Heliconia acuminata. Molecular Ecology Resources, 9, 1261-1264. http://dx.doi.org/10.1111/j.1755-0998.2009.02627.x

[28] Katzir, N., Danin-Poleg, Y., Tzuri, G., Karchi, Z., Lavi, U. and Cregan, P.B. (1996) Length Polymorphism and Homologies of Microsatellites in Several Cucurbitaceae Species. Theoretical and Applied Genetics, 93, 1282-1290. http://dx.doi.org/10.1007/BF00223461

[29] Danin-Poleg, Y., Reis, N., Tzuri, G. and Katzir, N. (2001) Development and Characterization of Microsatellite Markers in Cucumis. Theoretical and Applied Genetics, 102, 61-72. http://dx.doi.org/10.1007/s001220051618

[30] Watcharawongpaiboon, N. and Chunwongse, J. (2008) Development and Characterization of Microsatellite Markers from an Enriched Genomic Library of Cucumber (Cucumis sativus). Plant Breeding, 127, 74-81.

[31] Wang, S.Z., Pan, L., Hu, K., Chen, C.Y. and Ding, Y. (2010) Development and Characterization of Polymorphic Microsatellite Markers in Momordica charantia (Cucurbitaceae). American Journal of Botany, 97, e75-e78. http://dx.doi.org/10.3732/ajb.1000153

[32] Newstorm, L.E. (1985) Collection of Chayote and Its Wild Relatives. FAO/IBPGR Plant Genetic Resources Newsletter, 64, 14-20. 
[33] Grubben, G.J.H., Denton, O.A., Messiaen, C.M., Schippers, R.R. and Lemmens, R.H.M.J. (2005) Vegetables. Backhuys Publishers, Wageningen, 2.

[34] Ritschel, P.S., de Lima Lins, T.C., Tristan, R.L., Cortopassi-Buso, G.S., Amauri-Buso, J. and Ferreira, M.E. (2004) Development of Microsatellite Markers from an Enriched Genomic Library for Genetic Analysis of Melon (Cucumis melo L.). BMC Plant Biology, 4, 9. http://dx.doi.org/10.1186/1471-2229-4-9

[35] Cadena-Iñiguez, J. (2005) Caracterización morfoestructural, fisiológica, química y genética de diferentes tipos de chayote (Sechium edule (Jacq.) Sw.). PhD Thesis, Colegio de Postgraduados, Texcoco (in Spanish). 


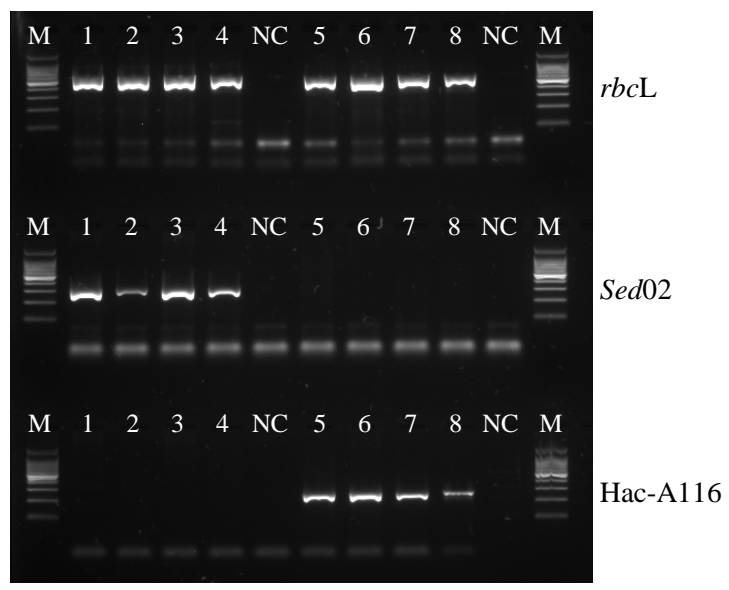

(a)

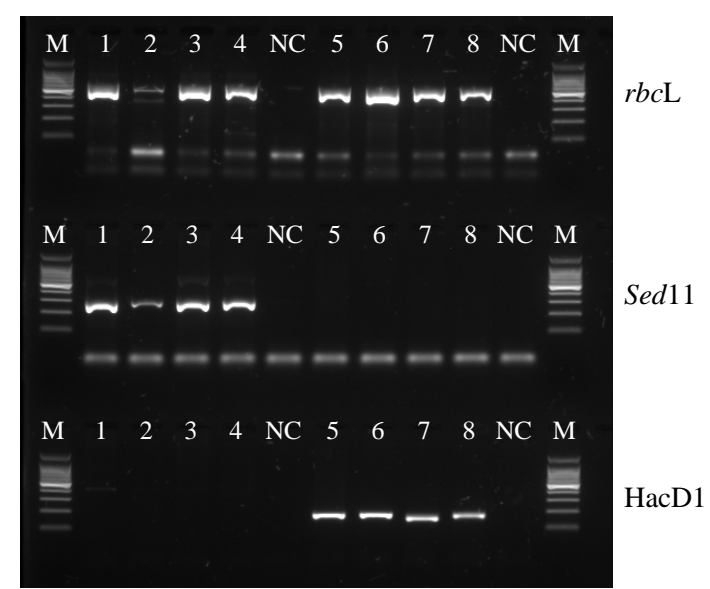

(b)

Supplementary Figure 1. Specificity of two designed microsatellite markers (Sed 02 and Sed 11) for chayote with DNA of other plant species (Heliconia acuninata). (a) PCR amplification with rbcL (positive control), Sed 02 (species specific markers to Sechium edule), and Hac-A116 (species specific marker of H. acuminata); (b) PCR amplification with $r b c L$ (positive control), Sed 11 (species specific markers to S. edule), and Hac-D1 (species specific marker of $H$. acuminata). M, molecular weight marker (100 bp DNA ladder); 1 - 4, four distinct genotypes of S. edule; 5 - 8, Heliconia sp.; NC, negative control (without DNA).

Supplementary Table 1. List of Mexican chayote (Sechium edule (Jaqcs.) Sw.) used in this study with distinctive fruit characteristics.

\begin{tabular}{|c|c|c|c|c|c|c|}
\hline Accession no. & Variety group name & Fruit color & Fruit shape & Fruit size $^{\mathrm{a}}$ & Taste & Spines \\
\hline SE-261 & albus minor & yellow & round & small & sweet & no \\
\hline SE-264 & nigrum levis & dark green & obovoid & medium & neutral & no \\
\hline SE-264(b) & nigrum levis & dark green & obovoid & medium & neutral & no \\
\hline SE-275 & albus dulcis & yellow & pyriform & small & sweet & no \\
\hline SE-277 & nigrum spinosum & dark green & pyriform & big & neutral & yes \\
\hline SE-284 & albus spinosum & yellow & pyriform & big & sweet & yes \\
\hline SE-286 & albus dulcis & yellow & pyriform & small & sweet & no \\
\hline SE-288 & albus levis & yellow & obovoid & medium & sweet & no \\
\hline SE-290 & virens levis & dark green & obovoid & medium & neutral & no \\
\hline SE-292 & nigrum levis & dark green & obovoid & medium & neutral & no \\
\hline SE-300 & nigrum spinosum & dark green & pyriform & big & neutral & yes \\
\hline SE-301 & virens levis & dark green & pyriform & medium & neutral & no \\
\hline SE-316 & nigrum spinosum & dark green & pyriform & big & neutral & yes \\
\hline SE-330 & albus minor & Yellow & round & small & sweet & no \\
\hline SE-331 & nigrum conus & dark green & conical & small & neutral & no \\
\hline SE-339 & nigrum xalapensis & dark green & pyriform & big & neutral & no \\
\hline $\mathrm{SE}-349^{\mathrm{b}}$ & nigrum minor & dark green & pyriform & small & neutral & no \\
\hline SE-349 & nigrum minor & dark green & round & small & neutral & no \\
\hline SE-354 & nigrum spinosum & light green & pyriform & medium & neutral & yes \\
\hline SE-369 & albus levis & Yellow & obovoid & medium & sweet & no \\
\hline
\end{tabular}

${ }^{\mathrm{a}} \mathrm{big}(10.5$ - $15 \mathrm{~cm})$, medium (5.7 - $\left.8.2 \mathrm{~cm}\right)$, small (>3 cm); ${ }^{\mathrm{b}}$ Both accessions share the same accession number but the fruit shapes are different. 